\title{
The Tyranny that Was the Greek Statue
}

\author{
By Michael Arvanitopoulos
}

\begin{abstract}
The Greek statue was once an irresistible academic problem that drove some of our greatest minds literally crazy, while the scholarly attempts to understand it were spilling into society and fertilizing Western education. Our postmodernist, nonchalant attitude towards this strange object has it locked in the museums, where nowdays it is no more than a casual tourist attraction. This is not because the question that was the Greek statue was ever really answered; rather that we gave up on it, perhaps because we believed our own excuses not to deal with it. Heidegger's questioning our relationship, as humans, with the Greek statue, allows a revisiting of the question of the ontological status of this hitherto unaccountable object, by shedding assumptions and introducing new evidence in the form of better-informed questions.
\end{abstract}

\section{The Forgotten Question}

In 1935 Elisa Marian Butler published The Tyranny of Greece over Germany, where she made some observations on what transpired when the German Romantics cast their eyes on Greek statuary art. Her launching motive was that she wasn't interested in what the Germans had made of the Greeks, but in what the Greeks had made of the Germans. The picture she painted was at the same time lofty and grim. She saw that in their interpretations the Germans tended to ignore logical obstacles, that they appeared unaware of the dangers involved in the discussion of ideas and ideals, and this is how they drove themselves crazy over the Greek statue. Hölderlin, Heine, and Nietzsche did lose their mind after all. "In what other country would the discovery of serenity, simplicity and nobility in art have brought about such dire results?," wondered Butler. ${ }^{1}$ And it wasn't just the German Romantics. John Boardman, the meat-and-potatoes British art historian who educated the generations of Oxfordians with his canonical works Greek Sculpture - The Archaic Period, and The Classical Period (1985), also tried to wrangle with the Greek tyranny. After two volumes of trying to justify the inexplicable, mainly through deterministic historical accounts where he attributed the "progress" of Greek statuary art to democracy and the Persian

*Plato Academy, Tampa, Florida, USA.

1. Elisa Marian Butler, The Tyranny of Greece over Germany (Beacon Press, Boston, 1958), 335. 
Wars, ${ }^{2}$ he had to admit: "Staring at these works, in picture, cast or original, does not explain them; indeed their familiarity to some degree deadens perception." 3

This "deadening of perception" did not only affect the British and the Germans, amongst other Europeans, but it is seen by contemporary scholarship to have tyrannized the Greeks themselves since antiquity. In her book Images in Mind - Statues in Archaic and Classical Greek Literature and Thought (2001), Deborah Tarn Steiner observes that: "[L]ate archaic and classical sculptors seem to have responded by depicting their gods with bodies that simultaneously declared their proximity to men and reminded the viewer of the breach between a familiar surface appearance and an ineffable, invisible reality that could be neither directly 'imaged' nor reproduced." 4

The breach of the borderline seen to separate what is human and innerworldly from what is invisible and godly, lies behind all the problems that have driven crazy the people who took issue with these mysterious objects which look so much like us and dwell in our world, yet without really belonging to it. The unanswered question why the beings of the world are reified into tangible, objective "things," while what is subjective and closer to man remains a mystery, was addressed by Martin Heidegger in the concluding lines of Being and Time (1927), where we read of this distinction: "Where does it arise from? Why is being 'initially' 'conceived' in terms of what is objectively present, and not in terms of things at hand that do, after all lie still nearer to us? Why does this reification come to dominate again and again?" 5 The Greek statue is the pivotal locus where the distinct entities of the thing-like and the human-like converge, since the statue itself surfaces as this very problem of whether it is a chiseled stone, or rather a god. Those of us who have the quick answer, that the statue can only be a chiseled stone, may be surprised to hear that this view belongs only to our own age of matter-of-fact, where the statues are locked in the museums and the question that they once were is now forgotten. But this was not always the case.

\section{The Question Persists}

We can coarsely distinguish at least three historical phases in Western thought where Greek statues have been either experienced, addressed, or understood as "gods" of some sort. The first phase was pre-reflective and thus

2. John Boardman, Greek Sculpture - The Classical Period (Thames \& Hudson Ltd, London, 1985), 20, 168.

3. Ibid., 240.

4. Deborah Steiner Tarn, Images in Mind - Statues in Archaic and Classical Greek Literature and Thought (Princeton University Press, 2001), 90.

5. Martin Heidegger, Being and Time, tr. Joan Stambaugh (State University of New York Press, 1996), 397. 
agnostic, the second was reflective but conceptually vacuous, and the third reflective and conceptually potent, but premised poorly enough to be deemed incomprehensible. The pre-reflective stage refers to Archaic Greece. The conceptually vacuous phase culminated with eighteenth and nineteenth century European romanticism, not only from the Germans, but as Athena Leoussi reports in her Nationalism and Classicism (1998), also from the British, the French, and smaller European countries that followed suit to the Continent's ideological superpowers. ${ }^{6}$ The third hermeneutical phase was prompted in the last century by Heidegger's radical metaphysics, which was based in his theory of art, itself found incomprehensible if read literally.

In our days the mysterious presence of the Greek statue has been brought down to, and its presence justified in our world, from its reification to the marble stone being configured by variant modes of predication. The canonical interpretations of the Greek statue have seen it either as a verisimilitudinal or generic representation of the human form (Rhys Carpenter, Gisela Richter), ${ }^{7}$ as an idealization of the perfect human body from a collection of beautiful parts (J.J Winckelmann, G.E. Lessing), ${ }^{8}$ as a historical accident (John Boardman, Ernst Buschor),${ }^{9}$ or as a climatological consequence (Polybius, Montesquieu) $\cdot{ }^{10}$ Yet, as I have argued elsewhere, ${ }^{11}$ the being of the Greek statue, what we mean and commit to when we say that "the statue is ...," cannot be established from these predicates, so that the Greek statue "is" neither of these modes of configuration. So the question persists: what is the Greek statue?

For one thing, God and the statue do share one foundational attribute, namely that they both violate the copula "is" in their syntactic appropriation for the understanding. Just like it is with the statue which cannot hold on to its worldly predicates, "God's" essential predicating attributes (God's being omnipresent, omnipotent, omniscient, the summum bonum, etc.) are not met with in nature. As Kant showed in the Critique of Pure Reason, the thatness and the

6. Athena Leoussi, Nationalism and Classicism (Great Britain: MacMillan Press Ltd., 1998), 45, 47.

7. Rhys Carpenter, The Esthetic Basis of Greek Art, of the Fifth and Fourth Centuries B.C. (Indiana: Indiana University Press, Bloomington, 1959), 92, 93; Gisela Richter, Archaic Greek Youths (London Phaidon, 1960), 148.

8. Johann J. Winckelmann, The History of Ancient Art (Tennessee: General Books LLC, 2009), 21; Gotthold Ephraim Lessing, Laokoön, transl. Ellen Frothingham (Boston: Roberts Brothers, 1887), 58.

9. John Boardman, Greek Sculpture - The Classical Period (London: Thames \& Hudson Ltd, 1985), 20, 168; Ernst Buschor, On the Meaning of Greek Statues (Amherst: The University of Massachusetts Press, 1980), 8.

10. See reference in David Irwin (ed.), Winckelmann Writings on Art (Cromwell Place, London Phaidon Press Limited, 1972), 5.

11. Michael Arvanitopoulos, "Ectoplasm in the Museum," Mouseion, Journal of the Classical Association of Canada, 2021. 
whatness of God in the elementary proposition "God is," do not derive from the copula. Nor do any other attributes people have given to God derive from nature. This evidence was enough for Kant to reject the possibility of the existence of "God."12 And yet God is an entity encountered in many of the world's native understandings independently of culture, although still dependent on the way that we in the West understand the notion of "God" as we try to interpret otherwise discrete and perhaps inscrutable perceptual cultures. If the idea of "God" persists despite the lack of objective evidence, this is another way to say that, just like in the case of the Greek statue, God can only be what it is not. In view of this essential affinity, could it be then that the unpredicated entity in question, the Greek statue, is the God or at least a god, the possibility of the existence of which Kant never examined as did his Romantic compatriots?

In what follows I will attempt to rekindle the question that has been forgotten after we locked the statue in the museum and forgot the inconvenient question that it stand for. To agitate the question of the ontological status of the statue is to revisit the seemingly naive question Heidegger asked in The Origin of the Work of Art, and which nevertheless, Western thought has failed to answer, namely: "On the usual view, the work arises out of and by means of the activity of the artist. But by what and whence is the artist what his is?"13

\section{When Does God Enter the Statue?}

Homeric Greece is said to have experienced culturally indigenous entities the kind of Blonde Youth, as "gods." Steiner notices a paradigmatic section in the Iliad, where the statue of Athena stands in the temple as the Trojan suppliant women arrive to ask for help, and "Pallas Athena turns her head away" from them. "At no point in the episode does the poet distinguish between the deity and the statue standing in the temple," writes Steiner, adding that theophanies and agalmatophanies are hard to tell apart, not only because the term theos and his "representation" are interchangeable, but also because the behavior of the Olympians "spills over" into the world. ${ }^{14}$

We note here that in the so-called realm of reason where Steiner belongs and addresses the issue, the statue she discusses is already assumed to be a "representation." The tacit transference of value imposed here destabilizes the Homeric experience of the entity in question in favor of justifying it exclusively

12. Immanuel Kant, Critique of Pure Reason, tr. Norman Kemp Smith, unabridged edition (New York: St. Martin's Press, 1965), 29.

13. Martin Heidegger, The Origin of the Work of Art, in Basic Writings, ed. David Farrell Krell, (New York: HarperCollins, 1993), 143.

14. Deborah Steiner Tarn, Images in Mind - Statues in Archaic and Classical Greek Literature and Thought (Princeton University Press, 2001), 135. 
from our own, rational standpoint, although as I have argued elsewhere the currently predominant canonical interpretation of the Greek statue as a representation or an idealization are only irrational pseudo-explanations. This transference of value from the realm of mythos to the realm of logos is not new. It clearly appears in Plato and is sustained throughout neoclassicism. We will see it in more detail reintroduced for modernity by Winckelmann and Lessing, where the idea of the statue as representation is imbedded in the title of Lessing's classic work How the Ancients Represented Death, of 1769.

The realm of mythos ended axiomatically with the inauguration of the realm of reason by the Socratic elenchus. Landmark critiques by Xenophanes, Plato, and Minucius Felix sharply distinguished between statue and god, at the expense of either or both. At the threshold between Archaic and Classical Greece, Xenophanes of Colophon brought the Olympian deities crumbling down to earth with his irreverent remark that mortals of different nations deem their gods in their own image and so would animals if they had gods, so that evidently it is not the gods that create mortals and animals, but the other way around..$^{15}$ The world's various mythological cosmologies, including that of Christianity, which understand "God" as the unilateral and at the same time universal provenance of world, are thus shunned with Xenophanes' relativistic observation. The statue cannot be god as a metaphysical, exocosmic being, because there isn't such a thing as "god" to begin with. God is a human invention, and the statue is a simulacrum of man's idea.

In Plato's metaphysics the statue was further demoted to an eidolon of an eidolon (the copy of a copy), since no mortal chiseling can perfectly duplicate the essential, eternal ideality of the human figure. The fleeting human reality only faintly mirrors perfect eternal truths. Here the statue cannot be an immortal god because at the very best it could only be a copy of mortal man. At this point it is also clear that the statue was already seen as the work of the artist. As paradoxical as this may seem to us, in Archaic Greece the artists had remained unknown and the statues were believed to have fallen from the sky. ${ }^{16}$ Given this newfangled admission, that there is no world-making god in the statue, Plato had nothing better to offer regarding the origin of the world, other than his concept in Timaeus of God the demiourgos as poet and father. ${ }^{17}$

Be that as it may, the then new but persisting to our days conventional assumption that the statue is made by the artist, an assumption that, as we will see, was challenged by Heidegger, opened up the possibility to doubt now the installation of the divine in the manmade object. "When does the god come into being?" asked the early apologist of Christianity Marcus Minucius Felix in the

15. Xenophanes, Diels-Kranz, fragments 14, 15, 16.

16. David Irwin, (ed.) Winckelmann Writings on Art (London: Phaidon Press Limited, 5 Cromwell Place, 1972), 115.

17. Plato, Timaeus, 28, a-c. 
third century. "The image is cast, hammered, or sculpted; it is not yet a god. It is soldered, put together, and erected; it is still not a god. It is adorned, consecrated, prayed to - and now, finally it is a god once man has willed it so and dedicated it. When does the god come into being?"18

\section{Does the Statue Represent God?}

The Germans, all of whom had either tacitly or explicitly accepted that the statue is the work of the artist, did not address Minucius Felix' logical concerns. They remained spellbound to Winckelmann's trance, basking under his epiphenomenal presumption that art is about beauty and unable to see or escape his aforementioned contradictions. God is merely represented, that is, installed onto the stone in a reductive chiseling away of what does not belong to the essence of a deity, and done so by means of the genius of the sculptor who, as Lessing observed, makes sure that the essence of the god is universalized by being made abstract: "The gods ... represented by the artist are not precisely the same as those introduced by the poet. To the artist they are personified abstractions which must always be characterized in the same way, or we fail to recognize them." 19

Minucius Felix's incredulity was thusly sidestepped by romantic historicism through the abstractification of the statue through universal concepts. The more recondite and adjective the German description of the essence of divinity in the statue, the more Greek paganism would be compatible to monotheism and thus less exposed to Christian critique. Winckelmann, whom Butler describes as "in trance ... uttering truths which did not apply to the object before him, but were associated with it in his mind," 20 trailblazed this abstractification by employing theoretical concepts such as clarity, nobility, simplicity, serenity, greatness, depth, and composure, in order to explain to his compatriots the "divine attributes of the human form" in the Greek statue. ${ }^{21}$ We see this in the often-quoted passage from his History of the Art of Antiquity:

The universal, dominant characteristic of Greek masterpieces, finally, is noble simplicity and serene greatness in the pose as well as in the expression. The depths of the sea are always calm, however wild and stormy the surface; and

18. Octavius, 22.5.

19. Gotthold Ephraim Lessing, Laokoön, tr. by Ellen Frothingham (Boston: Roberts Brothers, 1887), 58.

20. Elisa Marian Butler, The Tyranny of Greece over Germany (Boston: Beacon Press, 1958), 47.

21. Ibid., 108. 
in the same way the expression in Greek figures reveals greatness and composure of soul in the throes of whatever passions. ${ }^{22}$

Ultimately what drove the Germans crazy was that what they saw - just like the pre-Socratics did - to be real and true, i.e., that the statue is a god, was simply impossible. Thinking about it defied logic, since here the premises were true but the conclusion false. Winckelmann first drafted the maddening argument, speaking of "incorporeal forms," of "divine attributes from the human form," about the "more than human proportions of a deity." 23 The Wincelmannites only swarmed in like moths to the flame to further add such premises, in pronouncements which found in Greek statuary "god-like and youthful forms full of truth in illusion" (Herder), ${ }^{24}$ seeing there "heroes and gods take[ing] part in the action" (Lessing), ${ }^{25}$ opening up a dialogue with the statue, "Gods of Hellas, gods of Hellas/Can ye listen in your silence?" (Schiller); ${ }^{26}$ they saw "snow-white images of the gods" (Goethe), ${ }^{27}$ where "I became what I saw, and what I saw was god-like" (Hölderlin). ${ }^{28}$

A prime example of the deeply rooted confusions romantic historicism had sustained all along, is Lessing's translation of Pausanias' references to the term

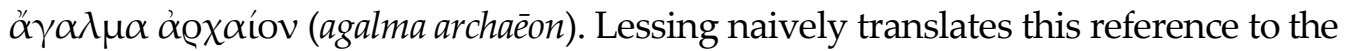

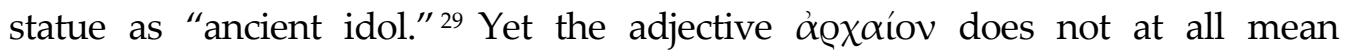
"ancient," but literally "grounding" as it derives from the noun $\alpha \varrho \emptyset \eta ́$ (archē)

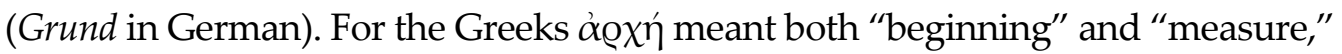
a measure that enacts a beginning. Likewise, $\alpha$ $\gamma \alpha \lambda \mu \alpha$ did not mean "idol" for the pre-Socratics, but "glorification," or "shining" "of the gods," a cognate to the verb $\alpha \gamma \lambda \lambda \alpha i \zeta \omega \omega$ (aglaizo) and the adjective $\alpha \gamma \lambda \lambda \alpha o$ s (aglaos); it has nothing to do with Plato's eidolon as copy and cognate of "idol." Similarly, the stone over which both the Christian apologist and the German neoclassicist troubled over of how the god could be installed into, was not as simple a thing as a "marble," that is, oryctologically speaking, the chemical element Calcium Carbonate, $(\mathrm{CaCO})$. The stone was understood from the noun $\mu \alpha \dot{Q} \mu \alpha \varrho o v$ (marmaron), derived from the

22. Ibid., 46.

23. David Irwin, (ed.), Winckelmann Writings on Art (London: Phaidon Press Limited, 5 Cromwell Place, 1972), 133, 76; Elisa Marian Butler, The Tyranny of Greece over Germany (Boston: Beacon Press, , 1958), 108.

24. Elisa Marian Butler, The Tyranny of Greece over Germany (Boston: Beacon Press, 1958), 77.

25. Ibid., 57.

26. J.C.F. Schiller, The Gods of Greece, 1-2.

27. Elisa Marian Butler, The Tyranny of Greece over Germany (Boston: Beacon Press, 1958), 98.

28. Ibid., 216.

29. Gotthold Ephraim Lessing, Laokoön, tr. Ellen Frothingham (Boston: Roberts Brothers, 1887), 174. 


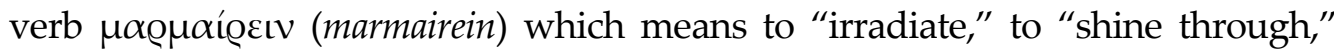
referring to the grounding, founding, and bestowing of the possibility of world as a mode of knowledge installed by the statue; or at least this is how Heidegger interpreted the meaning, out of his correct translation of the word.

I stated earlier that the Germans addressed the Greek statue with an approach that was abstract and reflective but conceptually vacuous. Our cursory historical account through Butler's panoramic view of the "tyranny" clarifies that this conceptual vacuity is the abortive outcome from a conclusion that denies its own premises. Lessing's misinterpretation transmogrified into an abstract concept what the pre-Socratic Greeks themselves had understood as a grounding of their own world experience. And Winckelmann's abstractification proved too weak to shake off the Christian apologist's question of exactly when the god comes into being in the stone. This would require a rigorous shakedown of the foundational presumptions of German romanticism; it would take the analyticalphenomenological return to the Greek phenomenon that would come only with Heidegger.

\section{Is it the Mood of the Statue that Makes It God?}

Heidegger radically parted with the German romantics, from a tradition sustained by Judeo-Greek metaphysics as a whole since the neoclassical interpretation of the Greeks. He did this mainly on three fundamental-ontological thrusts: First in arguing successfully contra Plato, Aristotle, and Christian theology, that God cannot be yet another being; secondly by showing that art is not about beauty but about truth; and thirdly in deconstructing realism and historicism by giving a brand new, critical meaning to the previously static concept of "world." The combination of these radical elucidations volatized the Greeks and led Heidegger to a quasi-archaic Gnosticism: the conviction that the Greek statue can be nothing but the presenting of god into a world of its own making as a mode of knowledge. This conviction somehow returned to and vindicated the Homeric experience of the statue, but now from thoroughly rational grounds not anymore liable to the accusation of mythological superstition.

Heidegger's theory of art cannot be accounted for here, far less his metaphysical superstructure upon which this theory is based and reciprocally justified. But a slice of his edifice can still illustrate his case. Heidegger escaped the romantic schizophrenia by now accepting the conclusion of its premising, namely that the statue is, or at least was, indeed as the premises established, a god. He did so by building up the arguments piecemeal throughout his extensive and labyrinthine works to conclude in The Origin of the Work of Art, one of his most impenetrable works, that it is be-"cause" of the Greek statue that world and its constituency is enacted as a perceptual contingency. We have his conclusion condensed in the following passage from Origin: 
The temple, in its standing there, first gives to things their look and to men their outlook on themselves. ... It is the same with the sculpture of the god ... It is not a portrait whose purpose is to make it easier to realize how the god looks; rather, it is a work that lets the god himself be present and thus is the god himself. 30

Since the statue is claimed to be "god" because it first gives to things their look and to men their outlook on themselves, Heidegger would have to demonstrate that the statue, as a statue, not only meets the conditions for the possibility of appearing in the world it determines, but far more so, that the statue is itself the condition for the possibility of human perception. So far we have seen that the entity in question does not even meet the first requirement, for it has defied the presumed conditions for the possibility of a canonical appearance in our world, as a representation, as an idealization, or as a historical accident. And now we are about to conclude that neither is it god. The failure to meet the first condition does not necessarily preclude the statue's meeting the second condition; in fact it may make it more likely, since for Heidegger god cannot be yet another world being. The dismantling of Western metaphysics begun from this core argument, which Heidegger postulated in Being and Time, namely that "The being of beings 'is' itself not a being." ${ }^{11}$ So far this is exactly what Blonde Youth is showing to "be," a non-being. But we are still far from having established that the statue is a god.

To prove that the statue is "god" at least on his own terms, Heidegger would have to show how human perception is absolutely determined by the statue, and done so without falling into the infinite regress which condemns the realism that hides behind the statue's interpretations as a representation, an idealization, or a historical accident. Indeed, Heidegger has compellingly moved away from the infinitism which always attributes one phenomenon as a causal result of another phenomenon, by having thoroughly replaced the concept of causality with the concept of grounding, notably the very same concept that truly defines the statue as $\dot{\alpha}$ @xaíov in the Greek language. With equal success he has also substituted the empiricist paratactic appearance of world objects to experience, with the structural integration of beings through the phenomenological concept of intentionality. But even after these, as radical as serviceable replacements, it still has to be shown how the non-causal, now structural relation between mortals and the marble god, is established in order to warrant perception of world as a mode of knowledge.

This would be viable if Heidegger could demonstrate that the structures of the understanding through which the modes of perception of mortals is possible,

30. Martin Heidegger, The Origin of the Work of Art, in Basic Writings, ed. David (HarperCollins: Farrell Krell, 1993), 168.

31. Martin Heidegger, Being and Time, tr. Joan Stambaugh (New York: State University of New York Press, 1996), 5. 
structures themselves grounded in the intentionality of a consciousness that is aware of its own impending demise (whence the identity of the "mortals"), are somehow related if not outright identical to and indistinguishable from the essential structures which constitute the statue. Arguably this interpretive endeavor is viable through the phenomenological reduction of the statue, where after the removal of all the knowledge that we bring and impose to the statue, i.e., the knowledge promulgated by realism and historicism, there would be nothing left to constitute and define the decontaminated object under the reduction, except these residual, essential structures.

The reduction, or bracketing of the object in question in an "epoché," is a standard phenomenological practice, trailblazed by Brentano and Husserl. Basically it is an analytical method of a privileged theory of perception, because unlike the theories which preceded it, this one begins from acknowledging the perceptual biases of the perceiver-investigator and accepting that every perceptual event is only an interpretation. In its existentialist projections the reduction reaches out to cancel our alienation from "the" world as this alienation is disseminated by realism; it confirms that world is of our own, human making, while at the same time we are the making of this world which for Heidegger is disclosed as a possibility by the metaphysical provenance of the Greek statue.

Since contra realism Heidegger does not arrive to art having started out from the object of perception that is the artwork, but the other way around, the reduction would not start from the human body in order to check the verisimilitudinal fidelity of the statue to the human body as the theorists of "Greek naturalism" saw it, since for them: "The human body in sculptural representation differs from its prototype, the living body, by calling attention to certain qualities which otherwise tend to pass unnoticed," to use the words of renown art historian Rhys Carpenter. ${ }^{32}$ Heidegger's interpretation would start instead from the phenomenologically reduced statue in order to check whether and how the residual world-disclosive determinants that constitute the essence of the statue are somehow related to and determine the intentional structures of human understanding.

Heidegger, however, did not produce a phenomenological reduction of the statue. The theory of embodiment implied from his fundamental ontology is notably still missing, although several attempts, including Maurice MerleauPonty's in Phenomenology of Perception, have advanced always mere ontological and ontic appropriations of body to world. ${ }^{33}$ Instead Heidegger diverted his attention from the statue to poetry and architecture, where the primordial

32. Rhys Carpenter, The Esthetic Basis of Greek Art, of the Fifth and Fourth Centuries B.C. (Bloomington, Indiana: Indiana University Press), 1959, 92, 93.

33. See also Kevin Aho, Heidegger's Neglect of the Body; Francisco J. Verela, The Embodied Mind; Shaun Gallagher, How the Body Shapes the Mind, etc. 
equipmentalization of intentionality that would embody the residual essences at large, are even more inscrutable.

Heidegger knew that the most primitive structure operative at the interface between what is human and what is world, is mood. For phenomenology moods are the most primitive world structures, preceding and determining the how and only thus the that of the phenomenal manifestation of beings in perception. Had Heidegger pursued the phenomenological reduction of the statue, and more so, the right statue, he may have noticed that a particular mood, the human mood of anxiety for the loss of world, argued by Heidegger as the most primordial of all moods, is precisely the residual essence that constitutes the non-being of the statue that exemplifies our case, the Blonde Youth.

In Being and Time Heidegger discusses this mood as a world-enacting mood: "In Angst [the human being] ... finds itself faced with the nothingness of the possible impossibility of its existence." 34 What Heidegger understands as the primordial, world-disclosive mood, I have argued elsewhere that it assembles what is otherwise canonically understood as the statue of the Blonde Youth. ${ }^{35}$ This is the primary reason why I myself have noticed this particular Greek "statue" and distinguished it out of some 400 surviving specimens that lie on either side of Archaic and Classical Greece.

Had Heidegger given a chance to prove that Blonde Youth is god, for Heidegger did visit in Athens these statues, ${ }^{36}$ the terms of his own fundamental ontology should have led him to the demonstration that the mood which constitutes the essence of this mysterious entity is, indeed, primordially determining human perception. For unlike any other world object, where the phenomenological reduction distills the human experience of the object reduced, the reduction of this statue could have yielded no less than the conditions for the possibility of human experience together with its object, the material thingliness of the statue. Such a world-forging yield could, indeed, at least begin to qualify, or increase the plausibility, that the entity in question as a god.

Nonetheless, in the absence of the phenomenological reduction of the statue Heidegger has left us with a non sequitur argument. Despite his accepting the conclusion his Romantic compatriots had rejected from seeing the statue only as $a$

34. Martin Heidegger, Being and Time, tr. Joan Stambaugh (New York State University of New York Press, 1996), 245.

35. Michael Arvanitopoulos, The Statue that Houses the Temple - A Phenomenological Investigation of Western Embodiment Making the Missing Connection between Heidegger and the Greeks, diss., University of South Florida, 2016.

36. Heidegger may have come face to face with Blonde Youth at his visiting the National Archaeological Museum in Athens, in 1967, as he wrote after that he had "... a view that halted the will to understand as it constituted something purely strange. However, this kind of strangeness was not frightening. It led to a world, which had been determined as the inception of a great destiny." In Martin Heidegger, Sojourns, State University of New York Press, 2005, p. 45. 
representation of the god, Heidegger's claim leaves his art theory still within the tradition of the assumptions that undermined the neoclassic movement. As a result, his claims in Origin that the statue is the god himself and that the statue discloses a world for the very first time, could not be taken seriously. Even Heideggerian phenomenologists like Julian Young resorted into saying that Heidegger could not have really meant what he claimed in Origin; that he was there only being "poetic."37

\section{The Blonde Youth Is Seer Mood}

We recall that Heidegger wrecked the superstructure of Western ontotheology on the single call that god cannot be yet another being. Thus if god cannot be yet another being, and the statue is a being, then the statue cannot be god. Conversely, if Heidegger held that the statue is a god, he must have also seen, without being explicit about it, that the statue is not a being. Thus, much of what remains to be decided, depends on our figuring out whether Blonde Youth is a being. The path through which Heidegger may have pursued such proof, i.e., the phenomenological reduction, could have decided this issue, but as we saw Heidegger did not take this path. Nonetheless, while in several of his works Heidegger investigated the relation between art and being, art and the artwork, art, the thing, and equipment; he still never claimed that the statue is not a being and how this would be possible.

Perhaps we could take this path and progress in this direction of establishing this particular "statue's" non-being-ness, by considering that since any other ontological predicates are derivatives of mood because mood is the most primordial structure that determines perception, then the one and only predicate that the entity in question may retain for itself, is its mood, where moods are not beings. Then, after we may have refreshed our understanding of what is a being, and whether mood is one of them, we could finally determine whether the entity in question is a being.

It is arguable, though we cannot commit to produce such proof here, that the phenomenological reduction of the Greek statue in general, and of Blonde Youth in particular, could distill its fundamental ontological essence as nothing but a certain mood. Mood in itself is not what we call a "world being;" it can only be reified as something else than itself, primarily and originally into human face and only secondarily into world objects in manufacture and architecture. The initial proof that to some degree moods in general, but more so this mood in particular that we perceive as Blonde Youth, are not of this world, is the fact and the reason why the planet's other animals, the ants, the snakes, the birds and the primates do

37. Julian Young, Heidegger's Philosophy of Art (Cambridge University Press, U.K., 2001), 31. 
have heads, but they have no face. The head is a kind of an extant being, or part of the world being that we call "body," but mood is not. By not constituting an extant being in itself, mood is coming from without to use the head and make face out of it in a way that the head cannot use mood. Thus by means of its being a mood and that alone, the only predicate it can hold on to, Blonde Youth is not an innerworldly being.

Phenomenology, Heidegger's predominantly included, has advanced our understanding of reality beyond empiricism and idealism from accepting that there are only two kinds of beings in the world: extant beings that are, and intentional beings that exist. The distinction between the two is sharp, although the ontological standing of the beings which merely are absolutely depends on the beings that exist. Thus when people say that a coffee mug, a primate, a talking computer, or god "exists," they are unwittingly abusing language and fool themselves into an inauthentic relation with the world by transgressing reality with category mistakes from either side of the two kinds of beings. It is a basic principle of phenomenology to recognize the particular meaning the Greeks gave

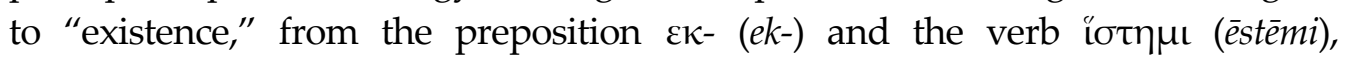
meaning something like: "to stand out," "to be open towards what one can be." From the original Greek understanding of "existence" we accept that only an intentional, that is, finite consciousness, a being that is human, can "exist," because in the ecstasis only a human being can step out of itself to be what is yet to be. The thing, on the other hand, "is" only as a res extensa, and the gods, being immortal, cannot be ecstatic; at the very best they only are just in case they are also found to be extant beings.

If Blonde Youth is to belong to our world, that is, if it is a being, it must qualify and be confined within either one of the two ontological qualifications of beings. If not, then it "is" not of this world. In order to "exist" the entity in question must be conscious, with a type of consciousness unlike that of mere living beings which can only die, or as Heidegger puts it, "perish." Existence, on the other hand, requires a consciousness which understands that it dies.

\section{Blonde Youth Is Not a Being}

As we saw earlier with Steiner, the Homeric Greeks seem to have experienced statues as beings of this type, as beings which exist, since they were indistinguishable from mortals because their agalmatophany spilled over into the world of the mortals. But this held only because the realm of mythos could not afford rational questions. Standing out open towards what one can be, is only one, but the fundamental ontological condition of existing beings. Besides this, there also apply the ontic or factical conditions of existence, now as a living being within the seamless network of life forms within a life-world. Living in the realm of logos is meeting the three biological conditions which determine all living 
organisms: to use and transform energy, to procreate, and to produce detritus. Arguably the entity in question meets none of these three conditions, therefore it is not alive and thus it does not exist. This checks out the first of just two possibilities for Blonde Youth to be a being of this world.

The other possibility would require that this "statue" could retain for itself as subject some ontological predicates in order to justify the copula that it is as a res extensa. We have already determined that Blonde Youth is nothing of what it has uncritically been thought of being (a representation, an idealization, or a historical accident), and thus the copula in proposition that "Blonde Youth is a statue," cannot afford predicates of its own in order to define itself. The three possibilities that we excluded may not be exhaustive, for someone may eventually come up with a new, better idea to explain this entity. But for now the entity in question fails the qualification not only of a "statue," but more so even of a res extensa, since none of our assumptions which could qualify Blonde Youth as a statue are defensible, and since art by itself and independently of the artwork as object does not extend in space.

The entity in question is a "statue" only if it is predicated as a representation, or an idealization, a historical accident, or a god. If it is neither of these attributions that predicate a "statue," then it cannot be as "statue." But then, what is it? Whether it is an $\alpha \hat{\alpha} \gamma \alpha \lambda \mu \alpha$, that is, a god shining through in Heidegger's understanding in grounding, founding, and bestowing world to its preservers as a mode of knowledge, this is an altogether separate question we have left behind with Greek mythology, German schizophrenia, and Heidegger's alleged poetry. To insist in credulity and granting it ontological status as it were by mere convention under the name "statue" is as a moot point if not altogether nonsensical as if we had agreed to call it a bathroom urinal or a spring vegetable. The ectoplasm is not a statue, for the same reason it is not a urinal or a vegetable: it cannot hold any predicates of its own or of any other object in order to establish its suchness as an eidos, a short of thing, into a legitimate object of perception.

From phenomenological grounds alone, where as Heidegger argued, the reification of the object of perception is itinerant within the existential, temporal horizon of the disclosure of beings, one may want to argue that mere convention can indeed legitimatize the object of perception. But even in this "subjective" horizon of interpretation that advances our understanding of reality beyond the shortcomings of empiricism and idealism, even there nothing can survive ontologically that is entirely arbitrary. Heidegger sharply outlined just two conditions under which the object of perception can be reified into a world appearance in the as-structure of interpretation: Extant beings are either as presentat-hand, or as ready-to-hand. Beings present-at-hand are those manifesting their eidetic suchness prior to explicit human intervention, but still within the holdings of human interpretation: natural objects such as galaxies, rivers, subatomic particles, milk, etc. On the other hand, beings which appear as ready-to-hand are those which have already undergone explicit human manipulation; they are 
objects like screwdrivers, submarines, vaccines, ice cream etc. In either of these two modes of appearance, objects of perception are reified strictly in terms of their serviceability, usability, or detrimentality, exclusively for a consciousness aware of and resisting its own finitude. ${ }^{38}$

The epistemological scandal that we casually understand as Blonde Youth satisfies neither of these two qualifications of appearance in the temporal horizon of disclosure of beings. It is not an object present-at-hand, because it is not a natural object; for some reason we cannot understand it other than as man-made. And it is not a ready-to-hand object, because it is not instrumental to the kind of world-dwelling consciousness that has a vested interest to enact the as-structure of interpretation in its temporal horizon of disclosure.

In terms of usability the entity in question is utterly useless, and the Greek peasants who in Christian times reportedly smashed and furnaced the ancient marbles reducing them to asbestolithic lime in order to plaster with it the walls of their houses, must have had a good old pragmatic grasp of this truism. The statue may have been thought of as useful if it did indeed represent or idealize something other than itself, useful as a means for a certain human community to reflect on itself; but as I have established by reference to another study of mine, this entity is neither a representation or an idealization.

In terms of serviceability, the entity in question is completely out of whack from the world-constitutive interrelations and interdependencies that serve the integration of the world's parts to the whole and vice versa. Blonde Youth affects no working order in the causal machinations of nature, nor is it affected by them. Since we eliminated the possibilities that it can be either a historical or hermeneutic accident, Blonde Youth is not part of the historical process and of natural law. Since Plato people have somehow accepted that the statue was made by an artist. But this assumption is only part of the cover up, since nobody has been able to answer Heidegger's seemingly naïve question by which we began our inquiry: "On the usual view, the work arises out of and by means of the activity of the artist. But by what and whence is the artist what his is?"

As for the third and last possibility, that Blonde Youth may have reified to appear in perception because of its detrimental effects to beings that exist in their resisting what resists their will to live, this ectoplasm seems pretty innocuous. It has not threatened or harmed anyone yet, save perhaps a handful of Germans with weak knees for serenity and simplicity. The tyranny that is Blonde Youth is nothing that we can think of, except maybe this very tyranny.

38. Martin Heidegger, Being and Time, tr. Joan Stambaugh (New York: State University of New York Press, 1996), 135. 


\section{Bibliography}

Aho, Kevin. Heidegger's Neglect of the Body. USA: Suny Press, 2010.

Arvanitopoulos, Michael. "Ectoplasm in the Museum." Mouseion, Journal of the Classical Association of Canada, 2021.

Arvanitopoulos Michael. The Statue that Houses the Temple - A Phenomenological Investigation of Western Embodiment Making the Missing Connection between Heidegger and the Greeks, diss., University of South Florida, 2016.

Boardman, John. Greek Sculpture - The Classical Period. Thames \& Hudson Ltd, London, 1985.

Buschor, Ernst. On the Meaning of Greek Statues. Amherst: The University of Massachusetts Press, 1980.

Butler, Elisa Marian. The Tyranny of Greece over Germany. Boston: Beacon Press, 1958.

Carpenter, Rhys. The Esthetic Basis of Greek Art, of the Fifth and Fourth Centuries B.C., Bloomington, Indiana: Indiana University Press, 1959.

Heidegger, Martin. Being and Time. Translated by Joan Stambaugh. New York: State University of New York Press, 1996,

Heidegger, Martin. The Origin of the Work of Art, in Basic Writings, edited by David Farrell Krell. New York: HarperCollins, 1993.

Heidegger, Martin. Sojourns. New York: State University of New York Press, 2005.

Irwin, David. (ed.). Winckelmann Writings on Art. London: Phaidon Press Limited, 1972.

Kant, Immanuel. Critique of Pure Reason. Translated by Norman Kemp Smith, unabridged edition. New York: St. Martin's Press, 1965.

Leoussi, Athena. Nationalism and Classicism. Great Britain: MacMillan Press Ltd., 1998.

Lessing, Gotthold Ephraim. Laokoön. Translated by Ellen Frothingham. Boston: Roberts Brothers, 1887.

Richter, Gisela. Archaic Greek Youths. London: Phaidon, 1960.

Steiner Tarn, Deborah. Images in Mind - Statues in Archaic and Classical Greek Literature and Thought. USA: Princeton University Press, 2001.

Verela, Francisco J. The Embodied Mind Cognitive Science and Human Experience. USA: The MIT Press.

Winckelmann, Johann J. The History of Ancient Art. Tennessee: General Books LLC, 2009.

Young, Julian, Heidegger's Philosophy of Art. U.K.: Cambridge University Press, 2001. 